\title{
PENGARUH KOMITMEN ORGANISASI DAN HUMAN CAPITAL TERHADAP KINERJA PADA KARYAWAN PT. FRISIAN FLAG
}

\author{
Agtovia Frimayasa ${ }^{1)}$, Suparman Hi Lawu ${ }^{2)}$ \\ ${ }^{1,2)}$ Universitas Bina Sarana Informatika \\ Email: ${ }^{1)}$ agtovia.avp@bsi.ac.id, ${ }^{2)}$ suparman.spm@bsi.ac.id
}

\begin{abstract}
Abstrak
Sumber daya manusia adalah salah satu elemen utama yang menempati posisi sangat startegis, artinya unsur manusia memegang peranan sangat penting untuk menjalankan aktivitas guna pencapaian tujuan perusahaan. Untuk itu sangat diperlukan komitmen kerja karyawan yang tinggi dan human capital yang mumpuni dalam rangka meningkatkan kinerja karyawan yang pada akhirnya akan meningkatkan daya saing perusahaan. Tujuan penelitian ini adalah untuk mengetahui dan menganalisis komitmen organisasi dan human capital baik secara parsial dan secara simultan terhadap Kinerja Karyawan. Penelitian ini dilakukan di PT. Frisian Flag Indonesia terhadap 100 karyawan dan data yang dikumpulkan diolah dengan regresi berganda dengan SPSS versi 23. Hasil penelitian menunjukkan bahwa komitmen organisasi berpengaruh positif dan signifikan terhadap Kinerja Karyawan, human capital berpengaruh positif dan signifikan terhadap Kinerja Karyawan, komitmen organisasi dan human capital secara simultan berpengaruh positif dan signifikan terhadap Kinerja Karyawan.
\end{abstract}

Kata kunci: Kinerja, Komitmen Organisasi, Human Capital

\begin{abstract}
Human resources are one of the main elements that occupy a very strategic position, meaning that the human element plays a very important role in carrying out activities to achieve company goals. For this reason, a high level of employee commitment and qualified human capital is needed in order to improve employee performance which in turn will enhance the company's competitiveness. The purpose of this study is to determine and analyze organizational commitment and human capital both partially and simultaneously on Employee Performance. This research was conducted at PT. Frisian Flag Indonesia for 100 employees and the data collected was processed by multiple regression with SPSS version 23. The results showed that organizational commitment had a positive and significant effect on employee performance, human capital had a positive and significant effect on employee performance, organizational commitment and human capital simultaneously had a positive and significant effect on employee performance.
\end{abstract}

Keywords: Performance, Organization Commitment, Human Capital

\section{PENDAHULUAN}

Kualitas yang dimiliki setiap SDM merupakan potensi sangat diperlukan untuk menunjang operasional perusahan dalam menjalankan kegiatannya sehari-hari dan pencapaian tujuannya. Keberadaan sumber daya manusia akan menentukan keberhasilan perusahaan. Oleh karena itu, perusahaan seharusnya memberikan perhatian bagi karyawannya sebagai timbal balik dalam merealisasikan tujuannya. Perhatian kepada SDM bertujuan agar menjaga keseimbangan antara energi yang dikeluarkan oleh karyawan dengan imbalan yang diperolehnya, sebab bila terjadi ketidakseimbangan antara perhatian perusahaan dengan pengorbanan yang diberikan karyawan maka kinerja karyawan akan menurun hingga akhirnya karyawan merasa tidak puas dan memilih mangkir dari perusahaan, akibatnya kinerja karyawan yang diharapkan oleh perusahaan tidak bisa terpenuhi.

Kinerja merupakan hasil kerja seseorang yang menggambarkan kualitas dan kuantitas atas kerja yang telah dilakukan. Kinerja antara satu orang dengan yang lainnya dapat saja berbeda, karena faktor-faktor pendorong yang berbeda. Kinerja karyawan sangat penting oleh karena kinerja seorang karyawan dalam sebuah instansi akan menentu $\neg$ kan efektif tidaknya kinerja instansi tersebut. Apabila kinerja karyawan tidak baik, maka kinerja instansipun menjadi tidak baik. Begitu juga sebaliknya 
apabila kinerja karyawan baik maka kinerja instansi pun menjadi baik (Mulyono, 2012). Kinerja yang baik mempengaruhi prestasi perusahaan secara keseluruhan, apabila kinerja pegawai rendah maka akan mencerminkan moral kerja yang rendah yang ditandai dengan turunnya semangat dan kegairahan kerja. Kinerja karyawan yang baik akan mempengaruhi tingkat produktivitas dan tujuan yang diharapkan oleh organisasi. Lebih jauh faktor kinerja pegawai tersebut dapat mempengaruhi kuantitas, kualitas, dan ketapatan waktu dalam usaha pencapaian tujuan.

PT. Frisian Flag Indonesia sebagai salah satu perusahaan susu terbesar di Indonesia selalu berusaha bersaing untuk mempertahankan kedudukan sebagai salah satu perusahaan yang unggul dibidangnya. Banyaknya kompetitor pada perusahaan susu membawa arus persaingan yang tidak lagi hanya pada price competition melainkan juga pada non price competition. Sumber daya manusia adalah salah satu elemen utama yang menempati posisi sangat startegis dalam PT. Frisian Flag Indonesia Plant Pasar Rebo, artinya unsur manusia memegang peranan sangat penting untuk menjalankan aktivitas guna pencapaian tujuan perusahaan. Untuk itu sangat diperlukan komitmen kerja karyawan yang tinggi dalam mendayagunakan sumber daya yang ada agar perusahaan dapat semakin hidup dan berkembang.

Seorang pekerja dengan komitmen organisasi, yang tinggi ataupun rendah akan memiliki sikap yang berbeda terhadap organisasi. Karyawan dengan komitmen organisasi yang tinggi akan menghasilkan performa kerja yang sesuai dengan harapan, rendahnya tingkat absen, dan rendahnya tingkat keluar-masuk (turnover) karyawan. Ketika komitmen diberikan kepada organisasi, maka perilaku psikologis yang diharapkan akan muncul melalui hubungan antara tujuan organisasi dengan karyawan. Karyawan yang loyal dan memiliki keterlibatan kerja, dan cenderung menghasilkan kinerja yang lebih tinggi (Luthans, 2008).

Pramadani dan Fajrianthi (2012) mengutip Griffin menyatakan suatu komitmen organisasional menunjukkan suatu daya dari seseorang dalam mengidentifikasikan keterlibatannya dalam suatu bagian organisasi. Komitmen organisasional dibangun atas dasar kepercayaan pekerja atas nilai-nilai organisasi, kerelaan pekerja membantu mewujudkan tujuan organisasi dan loyalitas untuk tetap menjadi anggota organisasi. Oleh karena itu komitmen organisasional akan menimbulkan rasa ikut memiliki (sense of belonging) bagi pekerja terhadap organisasi. Lebih lanjut, Pramadani dan Fajrianthi (2012) dengan menyadur Griffin menyatakan jika pekerja merasa dirinya terikat dengan nilai-nilai organisasional yang ada maka dia akan merasa senang dalam bekerja, sehingga kinerjanya dapat meningkat, seorang individu yang memiliki komitmen yang tinggi kemungkinan akan melihat dirinya sebagai anggota sejati organisasi, dan untuk melihat dirinya sendiri menjadi anggota jangka panjang dari organisasi. Sebaliknya, seorang individu yang memiliki komitmen rendah lebih cenderung untuk melihat dirinya sebagai orang luar, dan mereka tidak ingin melihat dirinya sebagai anggota jangka panjang dari organisasi. Seorang pegawai yang berkomitmen mengindikasikan adanya identifikasi dengan tujuan organisasi, perasaan tentang menjadi bagian dari organisasi dan rasa loyalitas. Pegawai yang berkomitmen merasakan nilai dan pentingnya integrasi tujuan individu dan organisasi (Pramadani, 2012). Penelitian Sudarman (2018) menghasilkan kesimpulan terdapat pengaruh yang signifikan secara simultan antara budaya kerja dan komitmen organisasi terhadap kinerja pegawai.

Selain komitmen organisasi, faktor human capital akan mempengaruhi kinerja karyawan. Human capital secara bahasa tersusun atas dua kata dasar yaitu manusia dan kapital (modal). Kapital diartikan sebagai faktor produksi yang digunakan untuk membuat suatu barang atau jasa tanpa mengonsumsinya selama proses produksi (Ritonga, 2019). Berdasarkan definisi kapital tersebut, manusia dalam human capital merupakan suatu bentuk modal seperti halnya mesindan teknologi. Manusia juga memiliki peran atau tanggung jawab dalam segala aktifitas ekonomi, seperti produksi, konsumsi, dan transaksi. Intellectual capital merupakan 
aset tidak berwujud (intangible asset) yang dimiliki oleh perusahaan, dan merupakan salah satu aset terbesar yang dimiliki oleh perusahaan. Human capital diartikan sebagai manusia itu sendiri yang secara personal dipinjamkan kepada perusahaan dengan kapabilitas individunya, komitmen, pengetahuan dan pengalaman pribadi. Walaupun tidak semata-mata dilihat dari individual tapi sebagai tim kerja yang memiliki hubungan pribadi baik di dalam maupun diluar perusahaan.

Human capital adalah pengetahuan, skill, dan pengalaman yang pegawai bawa ketika meninggalkan perusahaan, beberapa dari pengetahuan tersebut bersifat unik untuk tiaptiap individu, dan beberapa lainnya bersifat umum. Sebagai contoh: kapasitas inovasi, kreativitas, know-how dan pengalaman, kapasitas kerjasama, fleksibilitas pegawai, toleransi terhadap ambiguisitas, motivasi, kepuasan, kapasitas pembelajaran, loyalty, pendidikan formal dan pendidikan. Human capital meliputi pengetahuan tentang individu dari suatu organisasi yang ada pada pegawainya. Pegawai menghasilkan intellectual capital melalui kompetensi, sikap dan kecerdasan intelektual. Kompetensi termasuk keterampilan dan pendidikan. Sikap mencakup komponen perilaku dari pegawai. Kecerdasan intelektual menjadikan seseorang mengubah praktek dan memikirkan solusi yang inovatif terhadap suatu masalah (Starovic dan Marr dalam (Divianto, 2010).

Organisasi yang baik harus menerapkan human capital sebagai investasi perusahaan, adapun indikator yang termasuk dari human capital meliputi pendidikan, pengalaman, dan keterampilan yang dimiliki karyawan untuk menunjang kemajuan organisasi. Adapun pengalaman, pendidikan dan keterampilan merupakan bagian dari penunjang yang telah dirangkum pada saat ini yang disebut dengan human capital (Sukarti \&Kistyanto, 2014) Sukarti dan Kistyanto (2014) mengutip Ballout mengemukakan bahwa beberapa faktor human capital memasukkan tingkat pendidikan, investasi kerja, pengalaman kerja. Modalmodal tersebut merupakan modal manusia (human capital) yang harus terus dikreasi demi terciptanya inovasi. Sedangkan kinerja dibedakan menjadi dua, yaitu kinerja individu dan kinerja organisasi. Kinerja individu adalah hasil kerja karyawan baik dari segi kualitas maupun kuantitas berdasarkan standar kerja yang telah ditentukan, sedangkan kinerja organisasi adalah gabungan dari kinerja individu dengan kinerja kelompok.

Hasil penelitian Swastari, (2013) menyimpulkan bawah human capital managemen yang terdiri dari kompetensi, individual capacitiy dan individual motivation berpengaruh positif dan signifikan terhadap kinerja karyawan, begitupula hasil penelitian Sutia, Sabar. Sudarma, (2013) menghasilkan kesimpulan bahwa investasi modal manusia (human capital) dan orientasi strategis yang kuat akan meningkatkan kinerja perusahaan.

\section{TINJAUAN PUSTAKA}

\section{Kinerja Karyawan}

Manajemen adalah pengelolaan berbagai sumber daya yang dimiliki untuk mencapai tujuan yang telah ditetapkan, berbagai sumber daya yang ada harus ditetapkan dengan baik, diorganisasikan, digerakkan, dan diawasi sehingga penggunaanya tepat sebagaimana rencana yang ditetapkan, manajemen sumber daya manusia sebagai sumber daya atau asset yang utama, melalui penerapan fungsi manajemen maupun fungsi operasional sehingga tujuan organisasi yang telah ditetapkan dapat tercapai dengan baik (Sinambela. Lijan Poltak, 2016).

Kinerja adalah tentang apa yang dikerjakan dan bagaimana cara mengerjakanya (Wibowo, 2016). Kinerja merupakan performance atau unjuk kerja. Kinerja merupakan hasil dari suatu proses yang dilakukan manusia. Kinerja merupakan hasil pekerjaan yang mempunyai hubungan kuat dengan tujuan strategis organisasi, kepuasan konsumen, dan memberikan kontribusi pada ekonomi (Priansa \& Suwatno, 2016).

Indrasari (2017) dengan mengutip Bono dan Judge menyatakan mengukur kinerja dari banyak aspek. Terdapat tujuh kriteria yang dapat digunakan untuk mengukur kinerja karyawan secara individu yakni: 
a. Kualitas, yaitu hasil pekerjaan yang dilakukan mendekati sempurna atau memenuhi tujuan yang diharapkan dari pekerjaan tersebut,

b. Produktifitas, yaitu jumlah yang dihasilkan atau jumlah aktivitas yang dapat diselesaikan,

c. Ketepatan waktu, yaitu dapat menyelesaikan pada waktu yang telah ditetapkan serta memaksimalkan waktu yang tersedia untuk aktivitas yang lain,

d. Ffektivitas, adalah pemanfaatan secara maksimal sumber daya yang ada pada organisasi untuk meningkatkan keuntungan dan mengurangi kerugian,

e. Kemandirian, yaitu dapat melaksanakan kerja tanpa bantuan gursa menghindari hasil yang merugikan,

f. Komitmen kerja, yaitu komitmen kerja antara karyawan dengan organisasinya dan

g. Tanggung jawab karyawan terhadap organisasinya

Unsur-unsur yang digunakan untuk menilai kinerja karyawan sebagaimana dikemukakan oleh Flippo dalam Ramanda, Yuli \& Muchtar (2014) terdiri dari:

a. Kualitas kerja meliputi ketepatan waktu, ketelitian, keterampilan, dan ketepatan sasaran.

b. Kuantitas kerja meliputi keluaran yang tidak hanya berupa tugas rutin dan regular tetapi juga tugas-tugas ekstra dan mendesak.

c. Hubungan kerja yang meliputi perubahan pekerjaan, teman kerja, dan kerja sama dengan rekan kerja serta atasan.

d. Ketangguhan kerja meliputi kedisiplinan, inisitiatif, loyalitas, dan ketaatan pada peraturan yang telah ditetapkan.

\section{Komitmen Organisasi}

Komitmen organisasional didefinisikannya sebagai sebuah keadaan psikologi yang mengkarakteristikkan hubungan karyawan dengan organisasi atau implikasinya yang mempengaruhi apakah karyawan akan tetap bertahan dalam organisasi atau tidak, yang teridentifikasi dalam tiga komponen yaitu: komitmen afektif, komitmen kontinu dan komitmen normatif (Pramadani, 2012). Komitmen adalah suatu keadaan dimana seorang individu memihak organisasi serta tujuan-tujuan dan keinginannya untuk mempertahankan keangotaannya dalam organisasi (Robbins, Stephen \& Judge, 2014)

Pramadani (2012) mengutip Mowday menyatakan ada tiga aspek komitmen orgnisasi, yaitu :

a. Affective commitment, yang berkaitan dengan adanya keinginan untuk terikat pada organisasi. Individu menetap dalam organisasi karena keinginan sendiri. Kunci dari komitmen ini adalah want to.

b. Continuance commitment, adalah suatu komitmen yang didasarkan akan kebutuhan rasional. Dengan kata lain, komitmen ini terbentuk atas dasar untung rugi, dipertimbangkan atas apa yang harus dikorbankan bila akan menetap pada suatu organisasi. Kunci dari komitmen ini adalah kebutuhan untuk bertahan (need to).

c. Normative Commitment, adalah komitmen yang didasarkan pada norma yang ada dalam diri karyawan, berisi keyakinan individu akan tanggung jawab terhadap organisasi. Ia merasa harus bertahan karena loyalitas. Kunci dari komitmen ini adalah kewajiban untuk bertahan dalam organisasi (ought to).

\section{Human Capital}

Konsep human capital berdasarkan pada premis utama bahwa human capital menempatkan manusia bukan sekedar sumber daya, namun merupakan modal (capital) yang menghasilkan pengembalian (return) dan setiap pengeluaran yang dilakukan dalam rangka mengembangkan kualitas dan kuantitas modal tersebut merupakan kegiatan investasi (Salehudin, 2010). Divianto (2010) mengutip Becker menyatakan investasi untuk meningkatkan human capital adalah penting sebagai suatu investasi dari bentuk-bentuk modal lainnya. Skill, pengalaman, dan 
pengetahuan memiliki nilai ekonomi bagi organisasi karena hal tersebut memungkinkan untuk produktif dan dapat beradaptasi. Skill, pengetahuan dan kesehatan tidak hanya menguntungkan bagi seorang individu namun juga akan meningkatkan sumber daya bagi pengusaha dan suatu bangsa serta produktivitas potensial.

Peran human capital dalam penciptaan kekayaan intelektual (intellectual assets) sangat strategis, karena hanya human capital (SDM) yang dapat menciptakan pengetahuan dan sekaligus memiliki pengetahuan. Sedangkan pengetahuan itu sendiri merupakan unsur terpenting dalam proses penciptaan nilai organisasi/perusahaan, sehingga penciptaan nilai perusahaan sangat dipengaruhi oleh modal manusia (Christa, 2013).

Salehudin (2010) menyatakan ada beberapa hal yang diyakini akan membuat human capital berkembang, yaitu:

\section{a. Pengalaman.}

Karyawan yang sudah memiliki pengalaman pada suatu bidang akan beradaptasi lebih cepat dan berkontribusi lebih banyak sehingga dapat meminta gaji yang lebih tinggi daripada karyawan yang belum memiliki pengalaman sama sekali. Fresh graduate akan memiliki golden years selama 5-10 tahun pertama karir mereka, sebelum karir mereka mengalami maturity atau bahkan plateau dimana perkembangan karir mereka melandai atau bahkan datar sama sekali. oleh karena itu, seorang fresh graduate harus sangat berhati-hati memilih dimana dan bagaimana ia menginvestasikan waktunya.

\section{b. Pendidikan}

Pendidikan merupakan salah satu sumber modal manusia yang menjadi perhatian sejak awal. Pendidikan adalah investasi modal manusia dalam bentuk waktu dan biaya. Pendidikan juga dipandang sebagai salah satu bentuk investasi modal manusia yang paling penting, khususnya untuk meningkatkan tingkat pendapatan seorang karyawan.

\section{c. Pelatihan}

Pelatihan sebagai kegiatan investasi modal manusia yang terpenting kedua setelah pendidikan dan salah satu alat utama perusahaan untuk mengembangkan modal manusia yang dimiliki oleh karyawan mereka. Modal manusia ini dikembangkan dalam wujud kompetensi berupa keahlian (skill), pengetahuan (knowledge) dan sikap (attitude) yang dibutuhkan untuk dapat menyelesaikan pekerjaan dengan baik. Kompetensi yang dikembangkan ini dapat meningkatkan nilai karyawan di mata perusahaan sehingga dapat meminta gaji yang lebih tinggi, serta mengakses pekerjaan dan karir yang lebih baik.

\section{d. Modal Sosial}

Modal sosial (social capital) yang dimiliki karyawan memiliki keterkaitan yang kuat dengan modal manusia yang ia miliki. Salah satu penelitian menemukan adanya efek moderasi dari jejaring sosial yang dapat meningkatkan pengaruh modal manusia untuk mengakses pekerjaan dan karir yang lebih baik. Dengan demikian, jika terdapat dua karyawan yang memiliki modal manusia yang setara, maka karyawan yang memiliki modal sosial lebih besar akan memiliki probabilitas yang lebih besar untuk mendapatkan promosi dibanding karyawan yang memiliki lebih sedikit modal sosial.

\section{METODE PENELITIAN}

\section{Lokasi, Populasi dan Sampel Penelitian}

Penelitian ini dilakukan di PT Frisian Flag Indonesia yang beralamat di Jl. Raya Bogor KM 25 Pasar Rebo RT.5/RW.2 Gedong, RT.5/RW.2, Gedong, Kota Jakarta Timur, Daerah Khusus Ibukota Jakarta 13760. Pemilihan lokasi penelitian berkaitan dengan waktu dan tenaga yang dimiliki peneliti. Penelitian dilaksanakan pada bulan September 2019. Dalam penelitian ini, populasi adalah 
seluruh karyawan di PT Frisian Flag Indonesia divisi Quality Control, yang berjumlah sekitar 134 orang karyawan, peneliti menggunakan rumus Slovin untuk penentuan jumlah sampel dari populasi tersebut dengan tingkat kepercayaan 5\% untuk mendapat hasil sampel yang cukup terjangkau peneliti, dengan persamaan sebagai berikut:

$$
\mathrm{n}=\frac{\mathrm{N}}{1+N e^{2}}
$$

\section{Keterangan :}

$\mathrm{n} \quad=$ Ukuran Sampel

$\mathrm{N}=$ Ukuran Populasi

$\mathrm{e} \quad=$ Tingkat Kesalahan

Dengan populasi $(\mathrm{N})$ sebanyak 134 orang dan tingkat kesalahan (e) sebesar 5\%, maka besarnya sampel (n) dalam penelitian ini adalah: '

$$
\begin{aligned}
& n=\frac{134}{1+134(0.5)^{2}} \\
& n=\frac{134}{1+134 \cdot(0 \cdot 0025)} \\
& n=\frac{134}{1+0,335} \\
& n=\frac{134}{1,335}=100,3
\end{aligned}
$$

Berdasarkan perhitungan dengan rumus Slovin, maka jumlah sampel dalam penelitian ini dibulatkan menjadi 100 orang. Pada penelitian ini peneliti menggunakan metode Probability Sampling yakni simple random sampling. Simple Random Sampling adalah pengambilan anggota sampel dari populasi yang dilakukan secara acak tanpa memperhatikan strata yang ada dalam populasi itu. Metode pengumpulan data menggunakan kuesioner untuk mendapatkan data primer (Sugiyono, 2016).

\section{Analisis Data \\ Statistik Deskriptif}

Analisis secara deskriptif bermaksud untuk menjabarkan data yang diperoleh dari hasil pengumpulan data, diantaranya dengan mengetahui nilai rata-rata, modus, median dan lainnya.

\section{Uji Asumsi Klasik}

Beberapa asumsi yang harus dipenuhi terlebih dahulu sebelum menggunakan Multiple Linear Regression sebagai alat untuk menganalisis pengaruh variabel-variabel yang diteliti. Pengujian asumsi klasik yang digunakan terdiri atas uji normalitas, multikolinieritas, dan uji heterokedastisitas.

\section{Analisis Regresi Berganda}

Metode pengolahan data yang digunakan adalah regresi berganda dengan bantuan software SPSS 23. Metode regresi berganda yaitu metode statistik untuk menguji pengaruh antara beberapa variabel bebas terhadap satu

\begin{tabular}{|c|c|}
\hline Y & = Kinerja karyawan \\
\hline$\alpha$ & $=$ Intercept atau konstanta \\
\hline$\beta_{1}, \beta_{2}$ & $=$ Koefisien regresi \\
\hline $\mathrm{X}_{1}$ & $=$ Komitmen organisasi \\
\hline $\mathrm{X}_{2}$ & $=$ Human capital \\
\hline$\varepsilon$ & $=$ Error term \\
\hline
\end{tabular}
variabel terikat. Adapun model yang terbentuk dalam penelitian ini adalah:

$$
\mathbf{Y}=\mathbf{a}+\boldsymbol{\beta}_{1} \mathbf{X}_{1}+\boldsymbol{\beta}_{2} \mathbf{X}_{2}
$$

Dimana:

\section{HASIL PENELITIAN}

\section{Uji Validitas dan Reliabilitas}

Hasil uji validitas dapat dilihat pada tabel berikut:

\section{Tabel 1}

Hasil Uji Validitas Konstruk Variabel

\begin{tabular}{|l|c|l|l|}
\hline \multicolumn{4}{|c|}{ Uji Validitas Komitmen Organisasi } \\
\hline No & r hitung & r tabel & Ket \\
\hline 1 &, 698 & 0,3061 & Valid \\
\hline 2 &, 722 & 0,3061 & Valid \\
\hline
\end{tabular}




\begin{tabular}{|c|c|c|c|}
\hline 3 & ,596 & 0,3061 & Valid \\
\hline 4 & ,638 & 0,3061 & Valid \\
\hline 5 & ,763 & 0,3061 & Valid \\
\hline 6 & ,742 & 0,3061 & Valid \\
\hline 7 & ,649 & 0,3061 & Valid \\
\hline 8 &, 745 & 0,3061 & Valid \\
\hline 9 & ,617 & 0,3061 & Valid \\
\hline 10 & ,661 & 0,3061 & Valid \\
\hline 11 & ,666 & 0,3061 & Valid \\
\hline 12 & ,555 & 0,3061 & Valid \\
\hline 13 & ,690 & 0,3061 & Valid \\
\hline 14 & ,650 & 0,3061 & Valid \\
\hline 15 & ,700 & 0,3061 & Valid \\
\hline \multicolumn{4}{|c|}{ Uji Validitas Human Capital } \\
\hline No & r hitung & $r$ tabel & Ket \\
\hline 1 & ,654 & 0,3061 & Valid \\
\hline 2 & ,810 & 0,3061 & Valid \\
\hline 3 & ,708 & 0,3061 & Valid \\
\hline 4 & ,569 & 0,3061 & Valid \\
\hline 5 & ,764 & 0,3061 & Valid \\
\hline 6 & ,655 & 0,3061 & Valid \\
\hline 7 & ,708 & 0,3061 & Valid \\
\hline 8 & ,553 & 0,3061 & Valid \\
\hline 9 & ,801 & 0,3061 & Valid \\
\hline 10 & ,696 & 0,3061 & Valid \\
\hline 11 & ,847 & 0,3061 & Valid \\
\hline 12 &, 735 & 0,3061 & Valid \\
\hline 13 & ,790 & 0,3061 & Valid \\
\hline 14 & ,786 & 0,3061 & Valid \\
\hline 15 & ,761 & 0,3061 & Valid \\
\hline \multicolumn{4}{|c|}{ Uji Validitas Kinerja } \\
\hline No & r hitung & $r$ tabel & Ket \\
\hline 1 & ,732 & 0,3061 & Valid \\
\hline 2 & ,870 & 0,3061 & Valid \\
\hline 3 & ,820 & 0,3061 & Valid \\
\hline 4 & ,757 & 0,3061 & Valid \\
\hline 5 & ,706 & 0,3061 & Valid \\
\hline 6 & ,798 & 0,3061 & Valid \\
\hline 7 & ,763 & 0,3061 & Valid \\
\hline 8 & ,829 & 0,3061 & Valid \\
\hline 9 & ,782 & 0,3061 & Valid \\
\hline 10 & ,781 & 0,3061 & Valid \\
\hline 11 & ,705 & 0,3061 & Valid \\
\hline 12 & ,836 & 0,3061 & Valid \\
\hline 13 & ,825 & 0,3061 & Valid \\
\hline
\end{tabular}

\begin{tabular}{|l|l|l|l|}
\hline 14 &, 696 & 0,3061 & Valid \\
\hline 15 &, 747 & 0,3061 & Valid \\
\hline
\end{tabular}

Sumber: Data diolah, 2020

Berdasarkan hasil pengolahan data pada Tabel 1 , seluruh item pertanyaan pada variabel penelitian ini valid, sebab semua memiliki nilai $\mathrm{r}$ hitung >0,3061. sedangkan hasil uji reliabilitas dapat dilihat tabel berikut

Tabel 2

\section{Hasil Uji Reliabilitas Komitmen Organisasi}

Reliability Statistics

\begin{tabular}{|l|l|}
\hline Cronbach's Alpha & N of Items \\
\hline, 927 & 15 \\
\hline
\end{tabular}

Tabel 3

Hasil Uji Reliabilitas Human Capital

Reliability Statistics

\begin{tabular}{|l|l|}
\hline Cronbach's Alpha & N of Items \\
\hline ,949 & 15 \\
\hline
\end{tabular}

\section{Tabel 4}

Hasil Uji Reliabilitas Kinerja Karyawan

Reliability Statistics

\begin{tabular}{|l|l|}
\hline Cronbach's Alpha & N of Items \\
\hline 962 & 15 \\
\hline
\end{tabular}

Sumber: Data diolah, 2020

Berdasarkan hasil pengolahan data pada Tabel 1, 2, 3, dan 4. kuesioner variabel komitmen organisasi, human capital dan Kinerja reliabel, sebab memiliki nilai Cronbach's Alpha lebih besar dar 0,6.

\section{Statistik Deskriptif}

Statistik deskriptif yang disajikan dari hasil penelitian ini bertujuan memberikan gambaran secara umum mengenai penyebaran data yang diperoleh dilapangan. Hasil pengolahan data 
statistik deskriptif dapat dilihat pada tabel berikut:

\section{Tabel 5}

Statistik Deskriptif Komitmen Organisasi

\begin{tabular}{|l|l|}
\hline N Valid & 100 \\
Missing & 0 \\
Mean & 61,6700 \\
Median & 63,0000 \\
Mode & 66,00 \\
Std. Deviation & 7,70813 \\
Minimum & 41,00 \\
Maximum & 75,00 \\
Sum & 6167,00 \\
\hline
\end{tabular}

Sumber : Data diolah, 2020.

Berdasarkan hasil pengolahan data pada Tabel 3. skor variabel Komitmen Organisasi yang diperoleh dari para responden mempunyai ratarata 61,67 dengan simpangan baku 7,70, median sebesar 63, modus 66. Skor minimum 41 dan skor maksimum 75 .

\section{Tabel 6}

\section{Statistik Deskriptif Human Capital}

\begin{tabular}{|l|l|}
\hline N Valid & 100 \\
Missing & 0 \\
Mean & 55,8600 \\
Median & 56,0000 \\
Mode & 60,00 \\
Std. Deviation & 7,74077 \\
Minimum & 37,00 \\
Maximum & 75,00 \\
Sum & 5586,00 \\
\hline
\end{tabular}

Sumber: Data diolah, 2020

Berdasarkan hasil pengolahan data pada Tabel 4, skor variabel Human Capital yang diperoleh dari para responden mempunyai rata-rata 55,86 dengan simpangan baku 7,74, median sebesar 56 , modus 60, skor minimum 37 dan skor maksimum 75 .
Tabel 7

Statistik Deskriptif Kinerja Karyawan

\begin{tabular}{|l|l|}
\hline N Valid & 100 \\
Missing & 0 \\
Mean & 61,3100 \\
Median & 61,0000 \\
Mode & 60,00 \\
Std. Deviation & 6,93504 \\
Minimum & 43,00 \\
Maximum & 75,00 \\
Sum & 6131,00 \\
\hline
\end{tabular}

Sumber : Data diolah, 2020.

Berdasarkan tabel diatas skor kinerja karyawan pada Tabel 5, yang diperoleh dari para responden mempunyai rata-rata 61,31 dengan simpangan baku 6,93 median sebesar 61, modus 60, skor minimum 43 dan skor maksimum 75 .

\section{Uji Asumsi Klasik}

Hasil uji asumsi klasik dapat dilihat pada tabeltabel berikut.

\section{Tabel 8}

Uji Normalitas

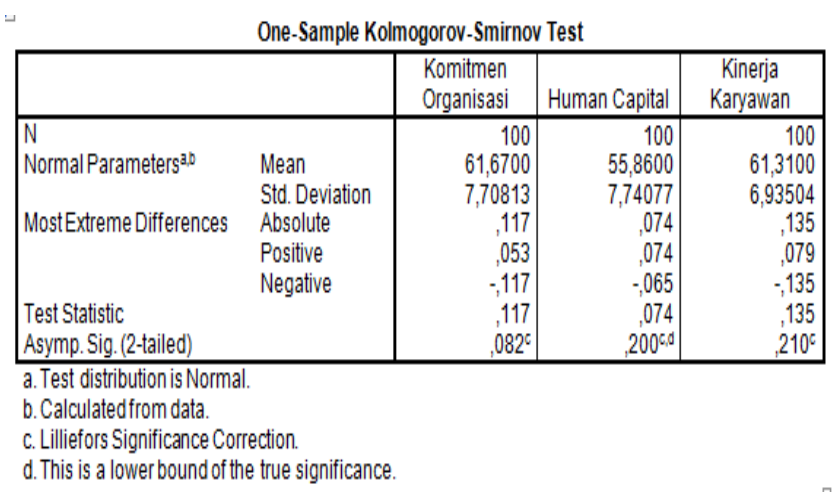

Sumber : Data diolah, 2020.

Pada tabel di atas terlihat bahwa nilai Asymp. Sig. (2-tailed) Kolmogorov-Smirnov untuk variabel komitmen organisasi sebesar 0,082, variabel Human Capital sebesar 0,200 dan variabel kinerja karyawan sebesar 0,210, semua nilai Asymp. Sig. (2-tailed) Kolmogorov-Smirnov lebih besar dari 0,05, sehingga $\mathrm{H}_{0}$ diterima, dengan kata lain bahwa data dari semua sampel pada penelitian ini berdistribusi normal. 
Tabel 9

Uji Multikolinieritas

Coefficients $^{\mathrm{a}}$

\begin{tabular}{|l|l|l|}
\hline \multirow{2}{*}{ Model } & \multicolumn{2}{|c|}{$\begin{array}{c}\text { Collinearity } \\
\text { Statistics }\end{array}$} \\
\cline { 2 - 3 } & Tolerance & VIF \\
\hline 1 (Constant) & & \\
Komitmen Organisasi &, 912 & 1,096 \\
Human Capital &, 912 & 1,096 \\
\hline
\end{tabular}

a. Dependent Variable: Kinerja Karyawan

Sumber : Data diolah, 2020.

Dari tabel 9 terlihat variabel bebas komitmen organisasi dan human capitl memiliki nilai VIF 1,096, lebih kecil dari $10(1,096<10)$, sehingga dapat disimpulkan tidak terjadi adanya penyimpangan asumsi klasik multikolinieritas antar variabel bebas dalam model.

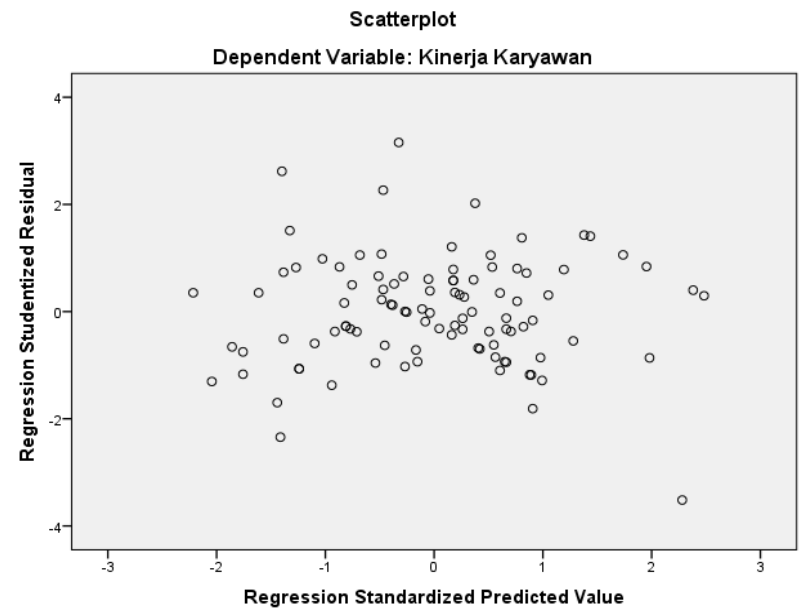

Sumber : Data diolah, 2020.

\section{Gambar 1. Uji Heteroskedastisitas}

Berdasarkan Gambar 1. terlihat bahwa dengan memplotkan nilai ZPRED (nilai prediksi) dengan ZRESID (nilai residualnya). Model yang didapatkan tidak terdapat pola tertentu pada grafik, sehingga model terbebas dari masalah heterokedastisitas.

\section{Analisis Regresi Berganda}

Berikut hasil uji regresi berganda pengaruh komitmen organisasi dan human capital terhadap kinerja karyawan.
Tabel 10

Koefisien Regresi

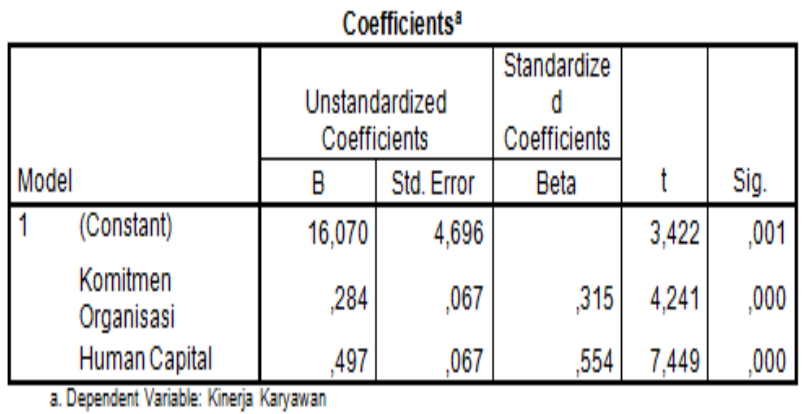

Sumber : Data diolah, 2020.

Dari hasil olah data diperoleh persamaan regresi berganda sebagai berikut:

$\widehat{\mathbf{Y}}=\mathbf{1 6 , 0 7 0}+\mathbf{0 , 2 8 4} \mathrm{X}_{1}+\mathbf{0 , 4 9 7} \mathrm{X}_{2}$

Berdasarkan persamaan regresi yang diperoleh, maka model regresi tersebut dapat diinterpretasikan sebagai berikut:

a. Koefisien konstanta sebesar 16,070 menunjukkan bahwa apabila nilai $\mathrm{X} 1$, dan $\mathrm{X} 2$ bernilai nol maka tingkat Kinerja sebesar 16,070.

b. Koefisien b1 sebesar 0,284 artinya apabila Komitmen Organisasi (X1) mengalami peningkatan sebesar satu satuan, sementara variabel lain bersifat tetap, maka variabel Kinerja (Y) akan berubah sebesar 0,284, dengan kata lain semakin tinggi Komitmen Organisasi akan meningkatkan kinerjanya.

c. Koefisien b2 sebesar 0,497 artinya apabila Human Capital (X2) mengalami peningkatan sebesar satu satuan, sementara variabel lain bersifat tetap, maka variabel Kinerja (Y) akan berubah sebesar 0,497, dengan kata lain semakin Human Capital akan meningkatkan kinerjanya.

\section{Tabel 11 \\ Uji F}

ANOVA $^{3}$

\begin{tabular}{|c|c|c|c|c|c|c|}
\hline \multicolumn{2}{|c|}{ Model } & Sum of Squares & $d f$ & Mean Square & $F$ & Sig. \\
\hline \multirow[t]{3}{*}{1} & Regression & 2428,867 & 2 & 1214,434 & 50,503 &, $000^{\circ}$ \\
\hline & Residual & 2332,523 & 97 & 24,047 & & \\
\hline & Total & 4761,390 & 99 & & & \\
\hline
\end{tabular}

Sumber : Data diolah, 2020. 
Dari pengolahan data pada Tabel 10 terlihat bahwa nilai Fhitung $=50,503$, sedangkan nilai Ftabel $=3,0892$, sehingga disimpulkan Fhitung $>$ Ftabel $(50,503>3,0892)$. Begitupula nilai Sig $\mathrm{F}=0.000$, lebih kecil dari 0,05, maka kesimpulannya H0 ditolak yang berarti bahwa koefisien regresi tersebut signifikan. Dengan kata lain bahwa terdapat pengaruh yang signifikan variabel bebas Komitmen Organisasi dan Human Capital secara bersama-sama terhadap variabel terikat Kinerja.

\section{Tabel 11}

\section{Koefisien Korelasi}

\begin{tabular}{|c|c|c|c|c|c|}
\hline Model & $R$ & RSquare & $\begin{array}{l}\text { Adjusted R } \\
\text { Square }\end{array}$ & $\begin{array}{c}\text { Std. Error of the } \\
\text { Estimate }\end{array}$ & Durbin-Watson \\
\hline 1 & $.714^{\mathrm{a}}$ & .510 & .500 & 4,90374 & 2,110 \\
\hline
\end{tabular}

Sumber : Data diolah, 2020.

Koefisien korelasi (r) adalah 0,714, hal ini berarti ada hubungan yang positif antara Komitmen Organisasi dan Human Capital dengan Kinerja dan hubungannya masuk dalam kategori kuat, sebab berada pada selang korelasi 0,600 - 0,799. Adapun besaran pengaruh persamaaan model memiliki Koefisien determinasi sebesar 0,510 menunjukkan bahwa besarnya kontribusi Komitmen Organisasi dan Human Capital secara bersama-sama terhadap Kinerja adalah sebesar $51 \%$, sisanya sebesar $49 \%$ disebabkan oleh faktor lain. seperti budaya organisasi, kompensasi, beban kerja, motivasi, kepuasan kerja dan sebagainya.

\section{PEMBAHASAN HASIL PENELITIAN}

Hasil penelitian ini sejalan dengan penelitian yang dilakukan Sudarman (2018), Ukkas \& Latif (2017), dan Anwar, Yusuf, \& Darmawati (2018) yang memberikan kesimpulan bahwa komitmen organisasi mempunyai pengaruh yang positif terhadap kinerja karyawan. Pegawai yang memiliki komitmen yang tinggi akan melakukan segala usaha agar dapat mencapai tujuan organisasi. Komitmen organisasi yang kuat akan mendorong para individu untuk berusaha lebih keras dalam mencapai tujuan organisasi. Sehingga komitmen yang tinggi menjadikan individu lebih mementingkan organisasi daripada kepentingan pribadi dan berusaha menjadikan organisasi menjadi lebih baik lagi. Komitmen organisasi yang tinggi akan meningkatkan kinerja yang tinggi pula. Komitmen didefinisikan sebagai suatu keinginan yang kuat untuk tetap menjadi anggota dari suatu organisasi. Keinginan ini ditunjukkan dengan menyerahkan segala upaya atas nama organisasinya dengan suatu keyakinan, penerimaan nilai dan tujuan dari organisasi tertentu. Komitmen organisasi ini ditunjukkan dengan sikap loyalitas pekerja secara terus menerus kepada organisasi untuk keberhasilan dan kesejahteraan organisasinya.

Hasil penelitian ini sejalan dengan hasil Penelitian Sutia, et al (2013), Swastari (2013) yang menghasilkan kesimpulan bahwa investasi modal manusia (human capital) akan meningkatkan kinerja. Human capital dipandang sebagai elemen strategik perusahaan karena pengelolaan dan kinerja sumber daya manusia memberikan kontribusi yang besar bagi penciptaan keunggulan bersaing (competitive advantage). Kemampuan mengelola sumber daya manusia sebagai aset yang penting bagi keberhasilan perusahaan seperti keahlian, pengetahuan, kemampuan dan perilaku tertentu dari manusia diperlukan untuk mencapai keunggulan bersaing, karena pada intinya manusialah yang akan mengimplementasikan strategi perusahaan. Apa yang dapat dihasilkan oleh manusia sesungguhnya tidak terlepas dari modal yang dimilikinya seperti pengetahuan, keahlian dan berbagai nilai lainnya yang memungkinkan vergeraknya modal finansial dan fisik. Modalmodal tersebut merupakan modal manusia (human capital) yang harus terus dikreasi demi terciptanya inovasi. Sedangkan kinerja dibedakan menjadi dua, yaitu kinerja individu dan kinerja organisasi. Kinerja individu adalah hasil kerja karyawan baik dari segi kualitas maupun kuantitas berdasarkan standar kerja yang telah ditentukan, sedangkan kinerja organisasi adalah gabungan dari kinerja individu dengan kinerja kelompok. 


\section{SIMPULAN}

Berdasarkan hasil penelitian, maka kesimpulan penelitian ini adalah yakni pertama, Hasil penelitian menunjukkan terdapat pengaruh yang signifikan variabel bebas Komitmen organisasi terhadap variabel terikat Kinerja, setiap kenaikan Komitmen organisasi akan menaikkan Kinerja. Kedua, Hasil peneliitan menunjukkan terdapat pengaruh yang signifikan variabel bebas Human capital terhadap variabel terikat Kinerja. setiap kenaikan Human capital akan menaikkan kinerja. Ketiga, Komitmen organisasi dan Human capital secara bersama-sama berpengaruh signifikan terhadap variabel terikat Kinerja. Keempat, Hubungan yang positif antara Komitmen organisasi dan Human capital dengan Kinerja, masuk dalam kategori kuat. Kontribusi Komitmen organisasi dan Human capital secara bersama-sama terhadap Kinerja adalah sebesar $51 \%$, sisanya sebesar $49 \%$ disebabkan oleh faktor lain. seperti budaya organisasi, kompensasi, beban kerja, motivasi, kepuasan kerja dan sebagainya.

Berdasarkan hasil penelitian, maka saran yang dapat diberikan adalah pertama, Manajemen PT Frisian Flag Indonesia, agar mempertahankan dan meningkatkan komitmen organisasi yang ada, sebab pengaruhnya secara parsial dan simultan terhadap kinerja signifikan artinya selama ini komitmen organisasi yang ada sudah baik dan meningkatkan kinerja. Kedua, Manajemen PT Frisian Flag Indonesia, agar mempertahankan dan meningkatkan human capitalkaryawan yang selama ini sudah berjalan, sebab human capitalbaik secara parsial maupun secara simultan memberikan kontribusi yang positif dan signifikan terhadap kinerja pegawai, human capital di PT Frisian Flag Indonesia dinilai karyawan sudah sangat baik. Keempat, Penelitian selanjutnya diharapkan dapat memasukkan variabel lain seperti budaya organisasi, kompensasi, beban kerja, kepuasan kerja dan sebagainya.

\section{DAFTAR PUSTAKA}

Anwar, S., Yusuf, M., \& Darmawati. (2018). Komitmen Terhadap Karyawan PT . Mutiara Di Kecamatan Mappedeceng. Equilibrium: Jurnal Ilmiah Ekonomi, Manajemen Dan Akuntansi, 7(1), 25-
33.

Christa, U. R. (2013). Peran human capital dan structural capital Dalam meningkatkan kinerja organisasi (suatu kajian konseptual). Jurnal Sains Manajemen Universitas Parahyangan, 1(1).

Divianto. (2010). Pengaruh Faktor-Faktor Intelectual Capital(Human Capital, Structural Capital dan Customer Capital) Terhadap Business Performance (Survey Pada Perusahaan Swasta Di Palembang). Jurnal Ilmiah Orasi Bisnis, IV(1).

Indrasari, M. (2017). Kepuasan Kerja dan Kinerja Karyawan: Tinjauan dari Dimensi Iklim Organisasi, Kreativitas Individu, dan Karakteristik Pekerjaan. Yogyakarta: Indomedia Pustaka.

Luthans, F. (2008). Organizational Behavior. New York: McGraw-Hill.

Mulyono. (2012). Pengaruh Kepemimpinan, Komunikasi, Motivasi, Pengembangan Karir, Dan Promosi Jabatan Terhadap Kinerja Pegawai Kantor Sekretariat Daerah Kabupaten Sukoharjo. Jurnal STIE AUB Yogyakarta.

Pramadani, A. B. \& F. (2012). Hubungan antara Komitmen Organisasi dengan Kesiapan untuk Berubah pada Karyawan Divisi Enterprise Service (DES) Telkom Ketintang Surabaya. Jurnal Psikologi Industri Dan Organisasi, 1(02).

Priansa, \& Suwatno. (2016). Manajemen Sumber Daya Manusia, Edisi Teori, Aplikasi dan Isu Penelitian. Bandung: CV. Alfabeta.

Ramanda, Yuli \& Muchtar, B. (2014). Pengaruh Human Capital, Relational apital dan Organizational Capital Terhadap Kinerja Pegawai (Studi Pada Badan Ketahanan Pangan Provinsi Sumatera Barat). Jurnal Pascasarjana Universitas Negeri Padang. Retrieved from

http://ejournal.unp.ac.id/index.php/jrmb p/article/view/5374 
Ritonga, Z. (2019). Analisis Pengaruh Human Capital Terhadap Kinerja Karyawan Pada PT.Mustika Asahan Jaya. Jurnal Ecobisma, 6(1).

Robbins, Stephen \& Judge, R. (2014). Perilaku Organisasi. Jakarta: Salemba Empat.

Salehudin, I. (2010). Invest In Yourself: Aplikasi Konsep Human Capital Dari Sudut Pandang Karyawan. Manajemen Usahawan Indonesia, 102.

Sinambela. Lijan Poltak. (2016). Manajemen Sumberdaya Manusia. Jakarta: Bumi Aksara.

Sudarman, E. (2018). Pengaruh Budaya Kerja Dan Komitmen Organisasi Terhadap Kinerja Pelayanan Publik Di Dinas Pariwisata Dan Kebudayaan Kabupaten Karawang. Prosiding Festival Riset Ilmiah Manajemen Dan Akuntansi.

Sugiyono. (2016). Metode Penelitian Bisnis. Bandung: Alfabeta.

Sukarti \&Kistyanto, A. (2014). Pengaruh Human Capital dan PersonEnvironment Fit Terhadap Komitmen Organisasi. Jurnal Ilmu Manajemen, 2(2).

Sutia, Sabar. Sudarma, M. D. \& R. (2013). The Influence of Human Capital Investment, Leadership and Strategic orientation on Airport Performance. Journal of Business and Management Invention, 2(611), 26-32.

Swastari, D. (2013). Analisis Penerapan Human Capital Management Terhadap Kinerja Karyawan Pada PT. Telkomsel Branch Purwokerto. Jurnal Fakultas Ekonomi Universitas Dian Nuswantoro.

Ukkas, I., \& Latif, D. (2017). Pengaruh Iklim Organisasi Dan Komitmen Organisasi Terhadap Organizational Citizenship Behavior (Ocb). Equilibrium: Jurnal Ilmiah Ekonomi, Manajemen Dan Akuntansi, $\quad$ 6(1). https://doi.org/10.35906/je001.v6i1.167

Wibowo. (2016). Manajemen Kinerja. Jakarta: PT RajaGrafindo Persada. 